\title{
'A soundtrack to the insurrection': street music, marching bands and popular protest
}

\author{
George McKay
}

I know that it's spring and dark winter is past when I hear the sound of the Protestant marching bands. It warms my heart to hear Protestant feet marching once again. For it is the marching bands that are keeping open roads for Protestants to walk upon. Unionist politician Ian Paisley, at a unionist parade in Northern Ireland, 1986

Hey, normal life ends here folks, there is a marching band in your Starbucks, you're not going to work today! Infernal Noise Brigade at Seattle anti-capitalist actions, $1999^{1}$

What happens in social movements when people actually move, how does the mobile moment of activism contribute to mobilisation? Are they marching or dancing? How is the space of action, the street itself, altered, re-sounded? The employment of street music in the very specific context of political protest remains a curiously underresearched aspect of cultural politics in social movements. ${ }^{2}$ Many campaigns are still reliant on a public display, a demonstration of dissent, which takes place on the fetishised space of the street. Such demonstrations claim (some activists say reclaim, suggesting a Golden Age of utopian past rather than future) the transient space of the street, occupy it in short-lived transformative experiments (the day of the march), and do so with sets of structures including what John Connell and Chris Gibson call 'aural architecture' (the live performance of marching music). ${ }^{3}$ What interests me here are the extraordinary sounds of this street music, which is not an everyday practice, but a music of special occasion. By looking at the marching bands of different sociopolitical and cultural contexts, primarily British, I aim to further current understanding of the idea and history of street music itself, as well as explore questions of the construction or repositioning of urban space via music- 'how the sound of music can alter spaces'; participation, pleasure and the political body; subculture and identity. ${ }^{4}$ These marching bands are resounding in their similaritieschoreography, the rhythm of drumming, uniforms, the contradictory gamut of military and pseudo-military practice-and also so very different from one anothercontextually, of course, but in terms of ideology, the politics of repertoire, gender, cultural tradition and innovation, too. For, while indeed social '[m]ovements are seen to be the breeding ground for new kinds of ritualised behaviour', as Ron Eyerman and Andrew Jamison have argued in Music and Social Movements, some common cultural practices can cut across campaigns in the mobilisation of tradition. ${ }^{5}$

According to Paolo Prato, the 'ambulatory way [...] of enjoying music [...] reveals itself to be the privileged way of the outdoors. A different kind of aesthetic pleasure is 
obtained through movement' ${ }^{6}$ The informal music played on the city street has been produced historically by marginal figures like the war invalid or other disabled person, the migrant group trading on the performance of a weak exoticism real (Italian organ-grinders) or invented (blackface minstrels), the more technically-adept Salvation Army brass band missionary project. Even earlier manifestations of street music included 'rough music' or charivari, featuring domestic utensils taken outside and used to make improvised music in an aural public gesture of communal disapproval or rivalry - a variation on expulsion through drumming out. Recent years have seen a new flourish of street music in the figure of the countercultural drop-out busker or community arts worker, or in identity-asserting public processions like the diasporic ones of calypso carnival and mela, or gay pride Mardi Gras. In these musical moments the street is less a space of social poverty, criminality or at least liminality — as formerly — than of cultural celebration and urban energy, 'suggest[ing] a vibrant cityscape [...] that challenges the anonymity (and alternative noises) of public space'. ${ }^{7}$ In the 'ambulatory way of listening' that occurs in the street, 'music becomes, on the one hand, a part of the environment and on the other hand a part of the body'-its sounds spread outwards and inwards. ${ }^{8}$ In the context of protest music in the street the rhythmic physical responses of marching or dancing to it are always also in part signs of pedestrian politics - the mass trespass or occupation, or defiant squat, of car-designated urban space, or 'the symbolic defence of territory (where you can or cannot “walk”)'. 9

Within popular music more generally the urban street is one focal zone not simply for activity and energy - the setting of 'authentic', usually masculinist, lyrics and videos - but also the street recurs within the landscape or mythography of pop's moments of political struggle for social change. Within the 1960s counterculture the Rolling Stones celebrated the masculine hero of the 'Street fighting man', while in the 1970s the British punk discourse of authenticity, anti-commercialism and workingclass consciousness was propounded through the notion of 'street credibility', and one of the leading punk political organisations, Rock Against Racism, declared: 'We want rebel music, street music'. ${ }^{10}$ From the 1980s on, African-American rap's privileged topos was the street of the ghetto or hood, where, in its view, contemporary black experience was most profoundly lived and represented. $21^{\text {st }}$ century anti-capitalist marching band Infernal Noise Brigade confirm the apparently now normative connection between the location of the street, the sounds of popular music and the imperative for action towards social change, propagandising that music 'embodies self-organization and incites people into "dancing ... on the ruins of multinational corporations".

These marching bands inspire joy, but also help move crowds, bringing reinforcements to high-intensity situations and renewing courage of those engaged in direct action. They also provide music —an essential component of carnival as it crosses barriers of nationality, ideology, and class. [...] Making music is a way of throwing beauty back into the streets - streets in which people really begin to live again. ${ }^{11}$

Such acts or claims of sonic territorialisation help to form the discursive practice in which profound arguments about, in Susan McClary's terms, 'what counts as noise, what counts as order, and who gets to marginalize whom' are aired. ${ }^{12}$ The marching bands I am looking at are dominated by male musicians, sometimes exclusively so; 
the public street as a space of masculine play and display is an expression of culture, power and privilege mirrored elsewhere in popular music, as Connell and Gibson point out.

Music contributes to the gendering and sexualisation of space through its role in the creation and maintenance of identity.... The contrast between ... the private home as the source of female happiness ... [and the] public street as a source of male power is redolent of the spatial gender divisions found in the lyrics of popular music. ${ }^{13}$

The performance of street music is heavily gendered and must therefore compromise the liberatory claims of at least some of the political movements it accompanies on protest. ${ }^{14}$ The domestic and public dynamic is approached in other ways too-the 'propaganda of sound' that is Infernal Noise Brigade distinguishes between 'ideology [a]s homework' and street music as political performance. ${ }^{15}$ Alongside these questions of cultural value and social power, there is also marching, or dancing, the physical movements inspired by street music; the embodied performance through public music is accessible in the sense that it can be witnessed by passers-by, and it 'create[s] collective identity and a sense of movement in an emotional and [...] physical sense'. 16

The 'unmusic' that is street music has often had an uneasy relationship with modernity, with urban authority, evidencing its irruptive potential. ${ }^{17}$ Murray Schafer has argued that '[i]t was not the result of legislative refinement but the invention of the automobile that muffled the voices of the street cries'. ${ }^{18}$ Yet arguably the earlier industrial transport noise of the railway competed first with the human traffic of the informal performance of music in the developing urban open space, while of course there was-and has continued to be-periodic action by government and local authorities to silence the sounds of music in their streets. Already, for example, in the 1830s in Paris there had been legislation passed to control street music. ${ }^{19}$ Most notoriously perhaps, a campaign by the professional classes of writers, scientists and teachers-people who, in the words of Charles Dickens and 200 other signatories were 'daily interrupted, harassed, worried, wearied, driven nearly mad, by street musicians'-in mid-Victorian London culminated in the Street Music Act, $1864 .^{20}$ The work of what John M. Picker describes as 'the anti-street music movement' of the time sought to 'expel the threat of the noisy rabble', a rabble which was not only noisy but (predictably perhaps) also largely foreign: the xenophobic undertone is clear in that favoured targeted groups were Italian organ-grinders and German brass bands - 'the street musician as [...] infectious, interruptive alien', in Picker's view. ${ }^{21}$ Though there had been various Procession Acts in Northern Ireland in the $19^{\text {th }}$ century 'in an attempt to curb sectarian parades and preserve public order', the more directly political period of social crisis, the Troubles from the late 1960s on, would produce its own legislation aimed at the strict control of street music. ${ }^{22}$ In the 1990 s the Parades Commission was established, a quasi-autonomous committee with the legal authority to control parades of marching bands by both Protestant and Catholic communities during the annual marching season across the province. The commission adjudicated on the frequency of parades, routes taken, numbers and types of marching bands (for example, pipe or the less threatening accordion), numbers of musicians, the carrying of flags and banners and insignia thereon. In an extraordinary sign of the level of detail involved-perhaps also a confirmation of the potential power of provocation of 
street music - the commission could even dictate the repertoire to be played by a band on the day of a parade. ${ }^{23}$

There is an argument that the continued focus on the street as the public space of dissent, of the kind of political culture I understand these marching musics to be, is itself an erroneous part of the contemporary activist problematic, a practical cul de sac. The American radicals Critical Art Ensemble boldly claimed in 1996—already their repeated argument- 'CAE has said it before, and we will say it again: as far as power is concerned, the streets are dead capital!' In this analysis, street fighting wo/man is redundant, reliant on outmoded tactics and locations of resistance, capable only of the reproduction of gestures of powerlessness.

Nostalgia for 60s activism endlessly replays the past as the present, and unfortunately this nostalgia has also infected a new generation of activists who have no living memory of the 60s. Out of this sentimentality has arisen the belief that the 'take to the streets' strategy worked then, and will work now on current issues. [... A]s capital has become increasingly decentralized, breaking through national boundaries and abandoning the cities, street action has become increasingly useless. $^{24}$

As we have seen, the socially-irritating sounds of street music did indeed figure importantly in 'the 60s' - the 1860s, as well as CAE's preferred 1960s. And, while greater surveillance, policing and legislation of urban spaces and public protest alike have been intended to render street action ever more 'useless', it is arguable that, if anything, in the years since CAE's statement the street as an articulation of communal space in which political ideas and culture are sounded and shared collectively has experienced a resurgence. This is evident locally, as in the annual confrontation between loyalist marchers, parade bands, Catholic residents, police and army in a small market town like Portadown in Northern Ireland from 1995 on, which managed to reverberate across British, Irish and US government edifices. It is evident globally, most obviously in the periodic 'global days of action' of what is known as the anticapitalist or anti-globalisation movement from the late 1990s on. In what ways has the collective socio-cultural experience of a phenomenon like street music on the march sounded politically, and (how) does it resonate still?

\section{'If I can't dance to it, it's not my revolution'}

Sounds, and the spaces they inhabit and transform, open up room to critique, to subvert and to reconstruct social realities. John Connell and Chris Gibson, Sound Tracks ${ }^{25}$

I have written elsewhere of the development of 'a leftist marching music of the streets' in British postwar campaign circles, which took new sounds from different repertoires to accompany the demonstrations of generations of activists from before, through and after the counterculture. ${ }^{26}$ Pivotal here is the Omega Brass Band, founded by the white English New Orleans-style jazz trumpeter Ken Colyer in 1955. The excitement for jazz fans of the Omega's establishment was clearly recalled and expressed to me half-a-century on, by now elderly members of the Ken Colyer Trust: 'We heard about it, all very excited, word spread like wildfire, through the rhythm 
clubs and record shops, through the LSE and St Martin's School of Art. This was the man's new project, and there was a great sense of anticipation'. ${ }^{27}$ From the first Soho Fair in London that year, the Omega-uniformed, choreographed, originating from the subcultural movement and cellar bars of the traditional jazz boom of the period, and viewed as authentic because leader Colyer had actually been to New Orleans and played the repertoire with black musicians there-quickly progressed to being a regular feature on marches and carnivals. Omega snare drummer Colin Bowden:

Of course, we might have got more political jobs because we played on the Aldermaston marches. If there was another socialist gathering, a May Day march for instance, well they'd book a parade band, to get the Aldermaston spirit, or feeling. In that way the two became connected, perhaps. The New Orleans style was swing on wheels, perfect for those marching occasions. On the other hand, the Musicians' Union would supply bands for say Trades Union events, and we weren't in the MU—we wouldn't have anything to do with it because of the [union] ban on American musicians that was still going on then. So that might have closed down other options. ${ }^{28}$

The use of street music on the Campaign for Nuclear Disarmament (CND) Aldermaston marches from 1958 on set the new leftist template of pop and politics here, and the Omega would mark the sense of occasion by leading the first or last mile of the three-day march, with a specially expanded line-up for added sonic and visual impact. The attraction and pleasure of live music on the march for the youth section of CND's constituency was integral to the carnivalesque identity of the event itself and to the campaign's politics. As one organiser of bands for Aldermaston explained: 'CND identified a fundamental flaw in conventional politics: let's live, not destroy the world. So: let's have a good time. So: music and dance! People thought about us: not only are they protesting, they're having a good time too! ${ }^{29}$ This 'good time' was achieved in the late 1950s and early 1960s by connecting the subcultural and pop enthusiasms of contemporary youth with the political action-music on the marchsounding the politics of youthful play and pleasure in deliberate contrast to what was perceived as the rational discourse of mass destruction. The imitation of the traditional African-American practice of 'second lining', that is, following alongside the marching jazz band, widened the procession out by reaching further into the street. Though only relevant to New Orleans-style parade jazz, this was one way in which music extended its impact on the political event, blurring the distinction between participants and observers in modest carnivalesque.

Over following decades the strategy of marching bands and political street music in Britain would be refreshed by government initiatives, such as the public funding of community arts in the 1970s, or would respond to what were considered more malign policy developments, such as the turn to privatisation and anti-Trades Union actions of the 1980s. When British jazz composer Mike Westbrook took his experiences of working in community theatre back into music, he sought to combine the participatory and accessible nature of street theatre with the visceral and visual impact of music performance. This led to the Westbrook Brass Band, formed in 1973.

The idea was to be able to play anywhere. So the music was acoustic, mobile, and open to all kinds of situations. We played in the streets, shopping centres, schools, hospitals, factory canteens — anywhere that anyone asked us. To find 
suitable material, I drew on New Orleans, folk songs, early music, anything at all that would work with that line-up. [...] It was anti-elitist, democratic, populist, yet High Art-for all of us, I think, a fusion of our musical and political philosophies. $^{30}$

The eclectic nature of the professional Brass Band's repertoire would be reflected a decade later in the work of the eponymously ideological Big Red Band, a Londonbased political group of primarily amateur street musicians formed in the political battleground mapped by the Thatcher years of the early 1980s. The Big Red Band played an avowedly and recognisably internationalist repertoire, a musical statement of its members' political sympathies which would be understood by its core audience at leftist demonstrations.

The fact that we had songs to fit the occasion made our contribution valuable, even when much more proficient bands were around. Often even the great miners' bands had no repertoire suitable for the occasion. [Ours consisted of e]verything we could find from collected books of left songs, folk songs, feminist songs, anticolonial, international, US labour movement, Victor Jara from Chile, the Beatles ... whatever we could lay hands on, and could persuade our teacher/arranger to put in a form we could play. ${ }^{31}$

Like the Omega and Westbrook Brass Bands of earlier decades, the Big Red Band's instrumental line-up drew heavily on brass (including trumpets, trombones, sousaphones), but a shift in instrumentation for political street music became evident within a few years. This was a result of factors including greater knowledge of international carnival practices, and the touristic or musical experience of these, as well as the developing global styles of world music, and the influence of dance culture, in the pop industry more widely. So, the 1999 Carnival against Capital in London-part of J18, a global day of action-was accompanied by a processional samba drum ensemble of activist musicians, called Barking Bateria, which in turn inspired the founding of Infernal Noise Brigade in the United States for the Seattle part of the next global day of action in November 1999. Jennifer Whitney of Infernal Noise Brigade tracks some of the very recent musical marching history here:

There have been marching bands like these at almost every global day of action since J18: the Committee for Full Enjoyment played at IMF/World Bank meetings in Washington in 2000, the INB turned up again in 2000 in Prague, as did Rhythms of Resistance, a samba band from London[....] New York’s Hungry March Band frequently delights crowds with their [sic] dance music and flashy baton twirling; the Front Musicale d'Intervention from France played the Zapatista hymn during the March for Indigenous Dignity in Mexico in 2001. ${ }^{32}$

With repertoires of percussive music for dancing to, at international events where crowds might speak different languages, a certain musical glamour could be added by the presence and performance of the marching band travelling from afar. The seriously ironic revolutionary art uniform of a band like Infernal Noise Brigade contributed a powerful visual stimulus and focal point (as of course had the Omega Brass Band's white shirts, black trousers and ties, peaked caps on Aldermaston marches four decades earlier), a jumble of signifiers enhanced by the sounds of the 
music and the choreography: 'Russian-style fuzzy black hats and militaristic green and black uniforms, flanked by a flag corps and rifle twirlers [...] our weird niche of an aesthetic (post-industrial, quirky-but-militant) [...] respirators with goggles as protection'.

\section{Rough music}

There is at least one vital (essential and thriving) tradition of marching bands in Britain which does not necessarily map onto an acceptable or comfortable (for Cultural Studies communities) set of ideological assumptions around post-1960s liberationist movements, such as anti-nuclear, pro-working class, anti-capitalist. Here the martial elements of the marching tradition are not so easily repressed nor ludicly subverted, but can be central, powerful and attractive aspects of the practice. Here also the sounded politics of the movers are culturally complex. While the Omega may have marched annually at Easter from Aldermaston and on May Day totalling, say, ten or twenty political appearances over the late 1950s and early 1960s, and the Infernal Noise Brigade lists around sixty appearances in its history from 1999 to disbanding in 2006, the scale of the Northern Irish parade tradition is massive in comparison. ${ }^{34}$ The streets of the province host a seemingly relentless parade culture during the annual 'marching season': in 1985 there were over 2000, in 1999 over 3300 parades, of which 2600 were by Protestant, unionist or loyalist groups, and 200 by Catholic or nationalist ones - the remainder included trade unionist and student processions. ${ }^{35}$ That the numbers are so detailed is evidence of the level of policing, surveillance and social control involved around the marching season.

Within the context of the civil unrest and inter-communal violence of the early 1970s, Protestant youth began to reclaim or reinvent the use of street music, with new pipe and drum bands. There was a shift in balance from the parade as a statement or celebration of religious and historical tradition to a more overt, sometimes uncompromising display of its political underbelly. According to Neil Jarman, this has led to bands on parade in the decades since then positioning themselves 'at the heart of loyalist political culture. [...] But they are also outside the control of the organisers of such events and they often represent contrasting political views to those of mainstream unionist opinion. They represent the "rough" side of unionism'. ${ }^{36}$ The generational change was evident in musical technique as well as difficulty of repertoire: 'The older members[' ...] elaborate regimental-style uniforms, expensive instruments and music holders testify to a more restrained musical tradition and social order. These are the competition-oriented bands, with "musical directors", employing musical arrangements utilizing harmony and counterpart. The younger "Blood and Thunder" bands usually use only single-key flutes which they play in unison, largely from memory'. ${ }^{37}$ Desmond Bell's keen eye for subcultural nuancing during his period of band study, the late 1980s, though criticised as overly subculturalist by Jarman, throws up some intriguing recontextualisations among band members and supporters: the mod's parka, with its red, white and blue logo or Union Jack flag, has a further local level of signification on a loyalist parade, while the punk's spiky hair is dyedorange.

As levels of social violence rose or became normative through the 1970s, some bands underwent what Bell calls a "“paramilitarization” of style'. ${ }^{38}$ This could be as subtle 
but unmistakeable as donning dark glasses, or more visual in terms of carrying flags or displaying the insignia of paramilitary organisations, including banned ones. Jarman confirms that 'many of the bands and bandsmen are highly politicised and [...] the connections with paramilitary culture are real and widespread.

Some bands appear in replica military uniforms and a few adopt paramilitary styled combat fatigues. [... T] The more radical types of bands used the parades to demonstrate their support for the more militant activists. As a result, [...] the Blood and Thunder bands have, for many, come to be seen as the public face of loyalist paramilitarism. ${ }^{39}$

Even while Adorno has reminded us that European youth embraced jazz and 'allowed itself to be electrified, as with marches, by the syncopated dance steps, with bands which do not by accident stem from military music', others have placed more faith in the power of syncopation, the space between the beats, the interweaving of crossrhythms, as metronomic opportunities for transformation. ${ }^{40}$ Omega Brass Band practiced a shuffle-step on the Aldermaston marches; Rock Against Racism demonstrators were 'steppin' to the music' on the march to the carnival in $1978{ }^{41}$ Infernal Noise Brigade 'agit-prop' explains the band's rhythmic purpose being to 'disrupt the dominant trance. Be calculatedly unpredictable and undermine the spectacle by introducing music of a disorienting or ecstatic nature into the sterile political discourse'. ${ }^{42}$ Each of these examples seeks to subvert the assumption or suspicion of the military trace in the movement of the music. The Northern Irish parade bands would appear to be the most martial and disciplined of the marching music considered here-unsurprisingly given that many parades commemorate past military campaigns (from, for Protestants, the Battle of the Boyne to the Battle of the Somme). Yet in other ways their music is the most compelling for it performs the dialectic, explores the tension in the very acts of playing and displaying, between 'the rigid musical discipline of their martial music' and its historical tradition, and 'the rhythmically-sophisticated, and improvisationally open’ sounds of contemporary pop sensibility.

It is perhaps more in the adaptation of the marching style itself on the streets that youth attempts to breathe some life into established tradition. We can list these stylistic innovations - the subversion of the military marching style in the exaggerated swagger and rhythmic shuffle of the fluters; the weaving dancers of the cymbal players who jaunt, crissing and crossing, through the ranks of the rest of the band almost in the manner of a country set dance; the antics of the bass drummers [careering into spectators...]; the vigorous, synchronised swirling of the flags by their bearers; the drum majors providing a touch of pure circus as they hurl their stocky decorated batons high into the sky above the crowd. ${ }^{43}$

Participating in the performance of music 'at political demonstrations is a ritual event. [...] Such preordained ceremonies serve to reunite and to remind participants of their place in a "movement" and also to locate them within a longstanding tradition of struggle and protest. [... Collective musical] rituals can also capture in a brief, transient moment, a glimpse of, and a feeling for, a spiritual bonding which is both rational and emotive at one and the same time'. ${ }^{44}$ What is missing here is at least the possibility of exclusion or intimidation from the music produced, any 
acknowledgement of the musical transmission of aggression. Such features can be understood as intrinsic to the type of music preferred by protestors—so, Infernal Noise Brigade could state that 'we wanted our music to be threatening'; a musical dialogue or argument develops as police truncheons beat on riot shields in a percussive call and response. In a reflexive loop, the music played could even be the music protested about-as when one campaigner against the notorious anti-rave clauses of the Criminal Justice and Public Order Act, 1994 explained that '[o]ne of the great things about rave music is that it winds the old bill [police] up something chronic'. ${ }^{45}$ Someone, whether musician or magistrate, understands musical aggression, for following an Apprentice Boys parade in Derry in 1995 two bass drummers were convicted of playing 'excessively hard' ${ }^{46}$ More soberly, while the celebration of the irruptive potential of the carnivalesque, the fetishisation of that proto-revolutionary moment, is a recurring critical trope in studies and activist rhetoric around street culture, music has also been a terrain of paramilitary murder in the context of Northern Ireland. ${ }^{47}$ In 1975, three members of the Miami Showband were executed by the Ulster Volunteer Force on their way home from a gig, while in 1989 the Irish Republican Army killed eleven mostly teenaged bandsmen with a bomb at the Royal Marine School of Music in Kent.

We have moved towards a discussion of order and chaos, which is dramatised for us in the eventful actions of the political marching band. Whether the campaign is paramilitary in strategy or pacifist in ideology, the marching band has a military origin, its impact is predicated on musical discipline, stylistic uniformity, and corporeal order. The protest on the other hand is most striking when it trips into carnival, its disruptive potential is unleashed. A familiar and dangerous ritual is enacted, the sometimes protracted finale presenting scenes which might include confrontation, violence, property destruction, riot, arrest, moral outrage. Usually the street music is battered and tacit now, sirens or calls replacing it in the chaos. But the soundtrack of insurrection is not only a thunderous, threatening, drumming noise-in fact, musical 'narratives may well be transitory and fragile, but when linked to social movements they can have lasting effects on individuals and societies' ${ }^{48}$ 
George McKay is Professor of Cultural Studies at the University of Salford, where he is Director of the Adelphi Research Institute for the Creative Arts and Sciences. He has written extensively on alternative cultures, cultural politics and popular music, including, most recently, as co-editor (with Pete Moser), Community Music: A Handbook (Lyme Regis: Russell House, 2005) and, as author, Circular Breathing: The Cultural Politics of Jazz in Britain (Durham NC: Duke University Press, 2005). He also co-edits Social Movement Studies: Journal of Social, Cultural and Political Protest (Routledge).

Adelphi House, University of Salford, Manchester M3 6EN, UK

tel. +441612952694

g.a.mckay@salford.ac.uk

\footnotetext{
Notes

${ }^{1}$ Paisley, quoted in Desmond Bell, Acts of Union: Youth and Sectarian Culture in Northern Ireland (London: Macmillan, 1990), p.127; Jennifer Whitney, 'Infernal Noise: the soundtrack to insurrection', in Notes From Nowhere Collective, eds., We Are Everywhere: The Irresistible Rise of Global Anticapitalism (London: Verso, 2003), pp.216-227 [p.224].

2 Though see George McKay, “'Just a closer walk with thee”: New Orleans-style jazz and the Campaign for Nuclear Disarmament in 1950s Britain’, Popular Music 22:3 (2003), p.261-81, and George McKay, Circular Breathing: The Cultural Politics of Jazz in Britain (Durham NC: Duke University Press, 2005), chs. 1 and 4.

${ }^{3}$ John Connell and Chris Gibson, Sound Tracks: Popular Music, Identity and Place (London: Routledge, 2003), ch. 9. Of course, during a demonstration the street is usually already transformed from the everyday, with an entire temporary infrastructure of contention: bodies and barriers, banners and shields, megaphones and surveillance cameras. In certain campaigns, those where the territory or accessibility of the street itself is part of the issue, it is further transformed materially: the lines of loyalist parade routes will be marked with kerbs painted red, white and blue; the TAZ-ers of a Reclaim the Streets radical environmentalist event cover tarmac in sand for a beach party. It is always only when the music strikes up, though, that people know the action has started.

${ }^{4}$ Connell and Gibson, Sound Tracks, p.193.

${ }^{5}$ Ron Eyerman and Andrew Jamison, Music and Social Movements: Mobilizing Traditions in the Twentieth Century (Cambridge: Cambridge University Press, 1998), p.13.

${ }^{6}$ Paolo Prato, 'Music in the streets: the example of Washington Square Park in New York City', Popular Music, 4 (1984), pp.151-63 [p.160].

${ }^{7}$ Connell and Gibson, Sound Tracks, p.193.

${ }^{8}$ Prato, 'Music in the streets', p.161.

${ }^{9}$ Bell, Acts of Union, p.55.

${ }^{10}$ On punk and 'street cred', see George McKay, “'I’m so bored with the USA”: the punk in cyberpunk', in Roger Sabin, ed. Punk Rock: So What? The Cultural Legacy of Punk (London: Routledge, 1999), pp.49-67 [pp. 57-58]. Rock Against Racism quotation is from David Widgery, Beating Time: Riot ' $n$ ' Race ' $n$ ' Rock ' $n$ ' Roll (London: Chatto and Windus, 1986), p.61.

${ }^{11}$ Whitney, 'Infernal Noise', p.216.

${ }^{12}$ Susan McClary, 'Afterword: the politics of silence and sound', in Jacques Attali, Noise: An Essay on the Political Economy of Music. [1977], trans. by Brian Massumi (Manchester: Manchester University Press, 1985), pp.149-58 [p.153].

${ }^{13}$ Connell and Gibson, Sound Tracks, p.211.

${ }^{14}$ It is not a purely masculine practice though, and the space of the street remains open for gendered détournements of the kind provided by, say, the radical cheerleaders of Portland, Oregon performing for anti-capitalists. Notes From Nowhere Collective, We Are Everywhere, p.89.

${ }^{15}$ Whitney, 'Infernal Noise', p.220.

${ }^{16}$ Eyerman and Jamison, Music and Social Movements, p.35.

${ }^{17}$ A term used by Victorian critics of street music, quoted in John M. Picker, Victorian Soundscapes (Oxford: Oxford University Press, 2003), p.62.
} 
${ }^{18}$ Quoted in Prato, 'Music in the streets', p.152. Despite this, street musicians have been by necessity interstitial and pragmatic; as David Cohen and Ben Greenwood note of the city busker, when the 'car has invaded his natural environment, so he has created another one in the Underground stations. When his audiences were stolen by the cinema, he played to them while they queued'. David Cohen and Ben Greenwood, The Buskers: A History of Street Entertainment (Newton Abbott: David \& Charles, 1981), p.167.

${ }^{19}$ Attali, Noise, p.74.

${ }^{20}$ Dickens, quoted in Picker, Victorian Soundscapes, p.60.

${ }^{21}$ Picker, Victorian Soundscapes, p.43, p.79. This xenophobia is overlooked as recently as 1970, when the Tenth edition of The Oxford Companion to Music's entry on 'Street music'- 'probably the first on its subject that has appeared in any musical work of reference' —still describes the 1864 campaign as one of 'well-justified agitation' (John Owen Ward, ed. The Oxford Companion to Music, $10^{\text {th }}$ edition, Oxford: Oxford University Press, 1970, pp.986, 990).

${ }^{22}$ Bell, Acts of Union, p.71.

${ }^{23}$ On the operation of the Parades Commission in Northern Ireland in the late 1990s, see Chris Ryder and Vincent Kearney, Drumcree: The Orange Order's Last Stand (London: Methuen, 2001), passim. Since then the social significance of the political soundscape of Ireland has been recognised in the Irish Republic, where, for instance, the Department of Foreign Affairs' 'reconciliation fund' has contributed to the establishment of a Cross-Border Pipe Music Tutorial Centre, bringing together marching bands from north and south of the border.

www.communityni.org/index.cfm/section/news/key/21junereconfund [5/09/2006].

${ }^{24}$ Critical Art Ensemble, 'Electronic civil disobedience', in Malcolm Miles, Tim Hall and Iain Borden, eds., The City Cultures Reader, $2^{\text {nd }}$ ed. (London: Routledge, 2004), pp.245-54 [p.246-47].

${ }^{25}$ Connell and Gibson, Sound Tracks, p.220. 'If I can't dance to it, it's not my revolution' comes from a slogan popular with 1990s environmental radicals and cultural autonomists, a misquotation attributed to the Lithuanian-American anarchist Emma Goldman.

${ }^{26}$ McKay, Circular Breathing. p.51; McKay, “"Just a closer walk with thee”'. The wider point is that other innovations in popular music, such as the folk revival or the rise of rock, did not entirely erase the specific usefulness of marching music on protest.

${ }^{27}$ Brian Harvey and Capt. Peter Hunter, members of Ken Colyer Trust, personal interview, 19 January 2002.

${ }^{28}$ Telephone interview, 10 April 2002. Bowden concluded: 'We also played fairs, fetes, carnivals.

There are a lot more funerals now to play at'.

${ }^{29}$ John Minnion, personal interview, 12 December 2001.

${ }^{30}$ Mike Westbrook, quoted in McKay, Circular Breathing, pp.217-18.

${ }^{31}$ Big Red Band founder-member Ben Crow, email correspondence, 16 October 2002.

${ }^{32}$ Whitney, 'Infernal Noise', p.216.

${ }^{33}$ Whitney, 'Infernal Noise', p.216, 219, 220.

${ }^{34}$ Note that this sum does not count tour dates since they are not listed separately on the band's

website. A guesstimate for total INB gigs would put the figure around 100 .

http://www.infernalnoise.org/dates.html [30/09/2006].

${ }_{35}^{35}$ Ryder and Kearney, Drumcree, p.2-3.

${ }^{36}$ Neil Jarman, 'For God and Ulster: Blood and Thunder bands and loyalist political culture', in T.G.

Fraser, ed., The Irish Parading Tradition: Following the Drum (Basingstoke: Macmillan, 2000), pp.158-72 [p.159].

${ }^{37}$ Bell, Acts of Union, p.100. Blood and Thunder bands were also known as Kick the Pope bands.

${ }^{38}$ Bell, Acts of Union, p.115.

39 Jarman, 'For God and Ulster', pp.161, 166-67.

${ }^{40}$ Theodor Adorno, 'Perennial fashion: jazz', in Prisms, trans. by Samuel and Shierry Weber (Cambridge Mass.: MIT Press, 1967), pp.119-32 [p.129]. Consider the argument put forward by Les Back on a 'syncopated sensibility' being an anti-totalitarian movement of the jazz body, for example. 'Syncopated synergy: dance, embodiment, and the call of the jitterbug', in Vron Ware and Les Back, Out of Whiteness: Colour, Politics and Culture (Chicago: University of Chicago Press, 2001), pp.16995 [p.193].

${ }^{41}$ RAR quotation is from Widgery, Beating Time, p.87.

${ }^{42}$ Quoted in Whitney, 'Infernal Noise', pp.218-19.

${ }^{43}$ Bell, Acts of Union, p.124-25.

${ }^{44}$ Eyerman and Jamison, Music and Social Movements, p.36. 
${ }^{45}$ Whitney, 'Infernal Noise', p.221; rave quotation from George McKay, Senseless Acts of Beauty: Cultures of Resistance since the Sixties (London: Verso, 1996), p.204, n.28.

${ }^{46}$ Jarman, 'For God and Ulster', p.163.

${ }^{47}$ One example of the celebration of carnival from prime TAZ-er, Hakim Bey (cartographer of the Temporary Autonomous Zone): 'The musician is a kind of "grotesque" — disobedient servant, drunk, nomadic, brilliant. For the musician the perfect moment is that of the festival, the world turned upside down. [...] The festival is nothing without the musician. [...] In the intoxication of conviviality in the carneval, music emerges as a kind of utopian structure or shaping force'. 'Utopian blues', www.gyw.com/hakimbey/utoBlues.html [n.d.] [21/09/2006].

${ }^{48}$ Eyerman and Jamison, Music and Social Movements, p.173. 